\title{
A comparative study of serum total thyroxine estimation on unextracted serum by radioimmunoassay and by competitive protein binding
}

\author{
PHILIP MARSDEN, PAUL FACER, MANUEL ACOSTA, AND P. J. N. HOWORTH \\ From the Departments of Medicine and Chemical Pathology, King's College Hospital Medical School, \\ Denmark Hill, London SE5
}

SYNOPSIS A rapid and precise radioimmunoassay (RIA) for serum total thyroxine $\left(\mathrm{T}_{4}\right)$ on as little as 1-10 $\mu \mathrm{l}$ of unextracted serum is described. Results in hypothyroidism (overt and borderline), in euthyroid subjects, in pregnant and oestrogen-medicated subjects, and in hyperthyroidism (overt and borderline) are compared with the results on the same sera by an established competitive proteinbinding technique (Ames' Tetralute) on unextracted serum from a different laboratory. The correlation between the two methods was excellent $(r=0.94)$ and no significant difference between overall results or results in any subgroup was found. In the hypothyroid range the radioimmunoassay appeared to measure total $T_{4}$ reliably in sera containing only 1.3 or $2.6 \mathrm{nmol} / \mathrm{l}$. Both methods predicted the clinical outcome in borderline hypothyroidism and borderline hyperthyroidism equally well and both gave normal results in $T_{3}$-toxicosis. It is concluded that both techniques reliably measure total $T_{4}$. RIA appears to have advantages of sensitivity and precision (especially in the hypothyroid range), of simplicity, and of low cost.

The determination of serum total thyroxine $\left(T_{4}\right)$ is still the most widely used single measurement employed in the clinical assessment of thyroid function (Chopra, 1972). Until recently the methods available largely relied on prior extraction of serum followed by competitive protein-binding (CPB) assay (Murphy, 1965) though CPB analyses on unextracted serum have recently been described (Bauer et al, 1970; Braverman et al, 1971). A new approach has been the use of radioimmunoassay (RIA) on unextracted serum for the measurement of total serum $\mathrm{T}_{4}$ and such techniques have been described by several authors (Chopra, 1972; Mitsuma et al, 1972; Beckers et al, 1973). However, discrepancies have been observed between the values of total $\mathrm{T}_{4}$ found by RIA and by CPB techniques. Chopra (1972) found that values in euthyroid and hyperthyroid subjects were higher by RIA; the difference was not thought to be due simply to losses in the extraction procedure employed in the CPB technique and was attributed to the presence in some sera of $T_{4}$ which was linked by covalent bonds to serum proteins and not extracted by butanol/ethanol. Received for publication 3 February 1975.
Similarly, Beckers et al (1973) found higher values in hyperthyroid subjects but not in euthyroid subjects or in pregnant women; and Ratcliffe et al (1974) found higher values by RIA in hyperthyroid subjects. However, Mitsuma et al (1972), in a comparison of results from hypothyroid, euthyroid, and hyperthyroid subjects, found excellent agreement (coefficient of correlation 0.98).

This paper compares total $\mathrm{T}_{4}$ estimation on unextracted serum by RIA and CPB techniques performed in two different laboratories.

\section{Methods}

Total thyroxine $\left(T_{4}\right)$ was measured by RIA on unextracted serum using the method of Mitsuma et al (1972) modified as stated below.

${ }^{125} \mathrm{I}_{-} \mathrm{T}_{4}$ (S.A. $25-50 \mathrm{mCi} / \mathrm{mg}$ ) was obtained from the Radiochemical Centre, Amersham instead of from Abbott Laboratories, Illinois; 25 pg was used as label in the assay without further purification and counting time adjusted to give 20000 counts above background in the zero control tubes. Mitsuma et al (1972) used $50 \mathrm{pg}$ of ${ }^{131}$ I-T $_{4}$. 
8-Anilino, 1-naphthalene sulphonic acid (ANS), Eastman Kodak Corp, was used to block $\mathbf{T}_{4}$ binding to TBG in a dose of $200 \mu \mathrm{g}$ per assay tube (instead of $175 \mu \mathrm{g}$ ) and was included both in standards and in diluted unknown sera. The assay was conducted in barbitone buffer $0.08 \mathrm{~mol} / \mathrm{l}$ to block $\mathrm{T}_{4}$ binding to thyroxine-binding pre-albumin (TBPA). The use of human serum freed from $\mathrm{T}_{4}$ and tri-iodothyronine $\left(\mathrm{T}_{3}\right)$ by charcoal stripping (Mitsuma et al, 1972) was obviated by using high dilutions of serum in buffer $(100 \mu$ l of $1 / 10-1 / 100$ dilution of test serum routinely, but even higher dilutions for some hyperthyroid sera). At these high dilutions the slope of the curve formed by the serial dilution of a hyperthyroid serum (serum $\mathrm{T}_{4}$ concentration $282 \mathrm{nmol} / \mathrm{l}$ ) followed exactly the standard curve constructed in buffer (fig 1). Figure 2 shows a comparison of standard curves made up in buffer and in three dilutions of $\mathbf{T}_{4}$-free serum; at dilutions of serum less than 1:10 the standard curve was displaced from the standard curve constructed in buffer but at serum dilutions of $1 / 10$ or higher the curvewas parallel. Owing to the sensitivity of the method specimens from hypothyroid, euthyroid, or hyperthyroid subjects could be appropriately diluted so that the percentage bound fraction fell on the steep portion of the standard curve (area of greatest precision), and even at the lowest dilution $(1 / 10)$ non-specific interference by serum is avoided. A hyperthyroid serum assayed in multiple dilutions from $1 / 25$ (4 $\mu$ l of serum) to $1 / 800(0.125 \mu$ l of serum) showed a value of $282 \mathrm{nmol} / \mathrm{l}$ with a coefficient of variation of $9.6 \%$. A hypothyroid serum assayed in multiple dilutions from $1 / 10$ (10 $\mu$ l of serum) to $1 / 25$ ( $4 \mu \mathrm{l}$ of serum) had a mean value of $4 \cdot 7 \mathrm{nmol} / 1$ with a coefficient of variation $14.9 \%$.

Non-radioactive standards of $T_{4}(12 \cdot 5-500 \mathrm{pg} /$ tube

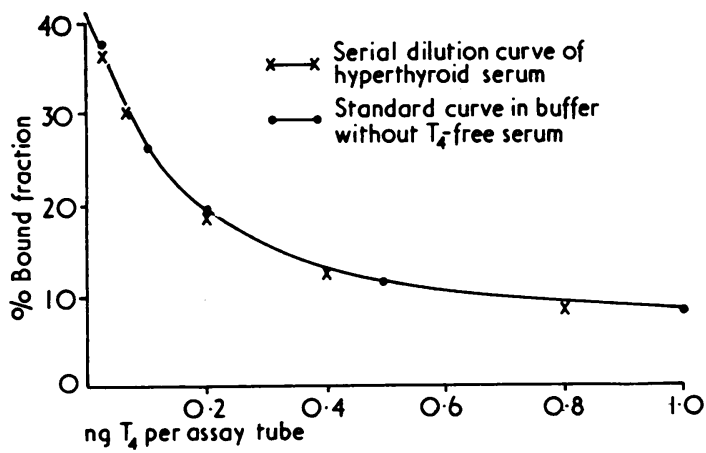

Fig 1 The curve formed by serial dilution of a hyperthyroid serum $\left(T_{4}\right.$ content $\left.282 \mathrm{nmol} / \mathrm{l}\right)$ assayed at 1/25 to 1/800 was parallel to the standard curve constructed without $T_{4}$-free serum.

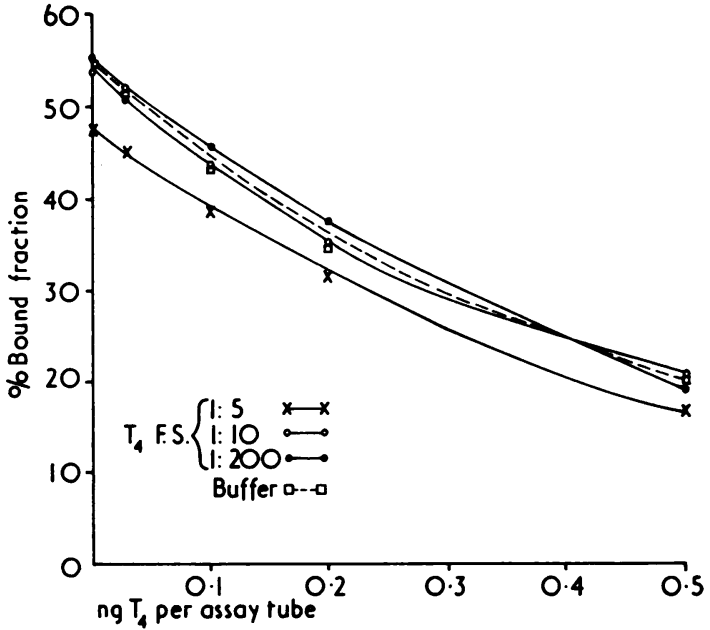

Fig 2 Standard curves constructed in the presence of $T_{4}$-free serum $\left(T_{4} F S\right)$ at dilutions greater than 1:10 were parallel with a standard curve not containing $T_{4} F S$. At greater serum concentrations the standard curve was displaced.

routinely) were derived by serial dilution in buffer of $\mathrm{T}_{4}(10 \mathrm{mg}$ of free acid) from Sigma Chem Co., dissolved initially in $0.13 \mathrm{M} \mathrm{NaOH}$ in $70 \%$ ethanol $(20 \mathrm{ml})$ and stored at $-20^{\circ} \mathrm{C}$. This stock solution was renewed monthly. Standards were made up fresh for each assay by serial dilution from the stock solution. Mitsuma et al (1972) used standards of $T_{4}$ of 0.1-5 ng per assay tube.

Antiserum to $T_{4}$ was produced in rabbits by injection of $T_{4}$ conjugated to bovine serum albumin prepared by the method of Gharib et al (1971). The antiserum showed $8 \%$ cross-reactivity with $\mathrm{T}_{3}$ as assessed by comparison of the doses of $\mathrm{T}_{4}$ and $\mathrm{T}_{3}$ required to inhibit binding by $50 \%$ from the zero control. Even if serum from a hyperthyroid patient with a serum $T_{3}$ concentration of $6.0 \mathrm{ng} / \mathrm{ml}$ were used at a dilution of only $1 / 10$, which would be unusual, the $T_{3}$ content $(60 \mathrm{pg})$ would cause a negligible depression of the percentage bound fraction. Cross-reactivity with mono- and di-iodotyrosine was not significant. The assay regularly detected $12.5 \mathrm{pg} \mathrm{T}_{4}$ equivalent to a serum concentration of $1.6 \mathrm{nmol} / \mathrm{l}$.

\section{ASSAY PROCEDURE}

$100 \mu \mathrm{l} \quad{ }^{125} \mathrm{I}-\mathrm{T}_{4}(25 \mathrm{pg})$

$100 \mu$ antiserum at $1 / 100$ initial dilution

$100 \mu$ diluted serum sample or $\mathrm{T}_{4}$ standard

$200 \mu \mathrm{l} \quad$ ANS $(200 \mu \mathrm{g})$.

The assay was run in barbitone buffer. Incubation was at $37^{\circ} \mathrm{C}$ for $1 \frac{1}{2}$ hours in a shaking water-bath. 
Separation of bound from free $T_{4}$ was achieved by a dextran-charcoal system essentially as described by Mitsuma et al (1972). The percentage bound fraction was counted overnight on a Packard Autogamma counter. The assay takes three hours apart from the counting and results are available the following morning.

\section{RECOVERY}

Recoveries were calculated by the addition of $T_{4}$ to euthyroid and hyperthyroid sera of which the basal $T_{4}$ content was also measured. For final $T_{4}$ concentrations of $87 \cdot 5-1588 \mathrm{nmol} / 1$ the mean recovery was $96 \%$ (range $91-105 \%$ ) in 10 experiments. Recoveries were also calculated in two experiments, by the addition of $T_{4}$ to $T_{4}$-free serum and found to be 95 and $102 \%$.

\section{PRECISION}

For hypothyroid, euthyroid, and hyperthyroid sera the within-batch SD of duplicate analyses was $2 \cdot 7,5 \cdot 3$, and $14 \cdot 8 \mathrm{nmol} / 1$, representing coefficients of variation of $19 \cdot 8,5.3$, and $7.5 \%$ respectively. The between-batch SD was $2 \cdot 2,5 \cdot 2$, and 17.5 nmol/l for hypothyroid, euthyroid and hyperthyroid sera respectively analysed in duplicate on consecutive assays. A quality control serum analysed over six assays had a coefficient of variation of $9 \%$ (mean value $295 \mathrm{nmol} / \mathrm{l})$.

\section{COMPETITIVE PROTEIN-BINDING}

Total $T_{4}$ by CPB was measured by the Ames Tetralute Sephadex column method (Howorth and McKerron, 1974) which included the modifications described by Gyde et al (1973). The coefficient of variation within-batch was $9.8 \%$ and between-batch was $12.7 \%$ (52 and 38 duplicate analyses respectively). Separate aliquots of the specimens were analysed by the two methods by separate laboratories over a period of several months, being kept deep frozen at $-20^{\circ} \mathrm{C}$ pending analysis.

\section{Subjects}

Fourteen of the hypothyroid subjects were overt clinical cases of myxoedema and all have shown a good response to subsequent treatment with $T_{4}$. Four subjects had dubious clinical evidence of hypothyroidism but all had an elevated serum TSH concentration; on follow-up three patients developed overt hypothyroidism responsive to treatment and one remained unchanged for a prolonged period. Of 30 euthyroid subjects, 16 were normal healthy volunteers and 14 were clinically euthyroid hospital outpatients.

Twelve subjects were taking contraceptive preparations containing $50 \mu \mathrm{g}$ of oestrogen and another 12 were pregnant.

Of the 18 hyperthyroid subjects, 14 were overt clinical cases of thyrotoxicosis and four cases were considered to be clinically borderline. The diagnosis in all cases was established by response to antithyroid medication. All 18 patients had an elevated serum $T_{3}$ concentration measured by RIA on unextracted serum (Marsden and McKerron, 1975).

\section{Results}

Excellent overall agreement was found between the two methods with a correlation coefficient of 0.94 (see fig 3).

The mean and SD of total $\mathrm{T}_{4}$ by each method in each subgroup of subjects is shown in the table. None of these differences is significant and there was no overall significant difference $(P>0.05)$.

\section{COMPARISON WITH CLINICAL DATA}

On the assumption that the normal range of 51.5 $141.6 \mathrm{nmol} / \mathrm{l}$ for total $\mathrm{T}_{4}$ established by the CPB technique (Howorth and McKerron, 1974) applies to both methods, the two methods were compared for their ability to predict clinical thyroid status.

\section{HYPOTHYROIDISM}

In overt hypothyroidism RIA gave 13/14 and CPB $14 / 14$ results below $51.5 \mathrm{nmol} / 1$. In borderline hypothyroidism each method gave the same results, three within the normal range and one below; one patient out of the four remained clinically unchanged for two years despite an elevated serum

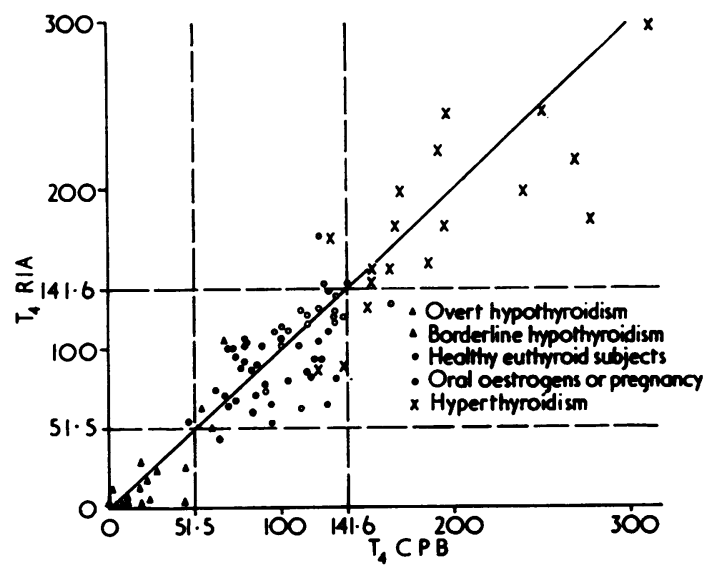

Fig 3 Correlation of serum $T_{4}$ concentrations (nmol/l) by radioimmunoassay $\left(T_{\mathbb{A}} R I A\right)$ and competitive protein binding $(T, C P B)$ in different groups of subjects.

The normal range is indicated by the interrupted lines. 


\begin{tabular}{|c|c|c|c|c|c|c|}
\hline & $\begin{array}{l}\text { Overt } \\
\text { Hypothyroid } \\
(14)\end{array}$ & $\begin{array}{l}\text { Borderline } \\
\text { Hypothyroid } \\
\text { (4) }\end{array}$ & $\begin{array}{l}\text { Euthyroid } \\
(30)\end{array}$ & $\begin{array}{l}\text { Oral Oestrogens } \\
\text { or Pregnancy } \\
(24)\end{array}$ & $\begin{array}{l}\text { Hyperthyroid } \\
\text { (18) }\end{array}$ & $\begin{array}{l}\text { Totals } \\
(90)\end{array}$ \\
\hline $\begin{array}{l}\text { RIA } \\
\text { CPB }\end{array}$ & $\begin{array}{r}7 \cdot 7 \pm 9.0 \\
14.2 \pm 15.4\end{array}$ & $\begin{array}{l}51.5 \pm 24.5 \\
52.8 \pm 18.0\end{array}$ & $\begin{array}{l}81 \cdot 1 \pm 14 \cdot 2 \\
88 \cdot 8 \pm 20 \cdot 6\end{array}$ & $\begin{array}{l}114.5 \pm 24.5 \\
115.8 \pm 20.6\end{array}$ & $\begin{array}{l}182.8 \pm 55.3 \\
195.6 \pm 55.3\end{array}$ & $\begin{array}{r}97 \pm 62 \\
104 \pm 64\end{array}$ \\
\hline
\end{tabular}

Table Comparison of the mean and $S D$ of total serum $T_{4}$ measured by radioimmunoassay $(R I A)$ and competitive protein binding $(C P B)$ techniques on unextracted serum

Figures in parentheses indicate numbers of subjects; units in nmol/1

TSH concentration ( $T_{4}$ normal by both methods); the other three patients became overtly hypothyroid despite normal $\mathrm{T}_{4}$ concentrations in two of them by both methods.

\section{Euthyroid subjects}

Each method gave only one value below $51.5 \mathrm{nmol} / \mathrm{l}$, otherwise all results were within the normal range.

\section{Oestrogens}

All 12 subjects on oral contraceptives fell within the normal range by RIA, 11 of them by CPB. Of 12 pregnant subjects, three were above the normal range by RIA and one by CPB.

\section{Hyperthyroid subjects}

For the four clinically borderline subjects RIA gave two results within the normal range and CPB gave three. In one of the clinically overt cases the CPB method gave a $\mathrm{T}_{4}$ slightly above and RIA slightly below the upper limit of normal; in the remainder results by both methods were elevated above normal.

\section{Discussion}

The radioimmunoassay described here is precise, simple, and cheap. Consumables and reagents cost approximately $£ 360$ per annum, to which may be added the estimated labour cost of $£ 500$ per annum (one-quarter of a technician's salary). The costing for the competitive protein-binding technique on the same basis was $£ 360$ for consumables and reagents, and $£ 1000$ for labour provided Sephadex columns are reutilized. Both methods are considerably cheaper than 'kits' commercially available. The annual sample load for the CPB method at the time of costing was 3000 samples and the RIA accommodates this number or more on the cost analysis given.

A new methodological feature is the non-dependence on $T_{4}$-free human serum which other assays have employed (Mitsuma et al, 1972). This is made possible by measurement of $T_{4}$ in serum at high dilution. Any tendency for a serum effect as described for the $T_{3}$ immunoassay (Mitsuma et al,
1972) on this assay would result in RIA concentrations appearing falsely higher than values by competitive protein-binding, which is clearly not the case.

A further feature of the RIA resulting from the sensitivity of the method is the opportunity to dilute the specimen so that the $T_{4}$ content falls on the steep (precise) portion of the standard curve. The sensitivity and precision are greater than those reported for most CPB techniques and are of particular value in the measurement of hypothyroid specimens. The use of such small volumes of serum as described here may well be of advantage in paediatrics or other circumstances where it is difficult to obtain blood by routine venepuncture, or in experimental work employing small animals.

Other workers have described higher values for total $\mathrm{T}_{4}$ by RIA than by CPB as mentioned in the introduction. The CPB techniques employed have largely relied on a prior extraction of serum and it has recently been shown that the recovery of $T_{4}$ may fall off progressively with higher total serum $T_{4}$ concentrations when using such a technique (Hehrmann and Schneider, 1974). The very close agreement in total $T_{4}$ concentrations and in prediction of clinical status found over a wide range of subjects by the two assays described here, which are both performed on unextracted serum, suggests that the previously described difference between the two techniques may well be an artefact of extraction procedures, particularly as identity of results has been described when $T_{4}$ is measured by RIA and CPB on extracts of serum (Chopra, 1972) or when $\mathrm{T}_{4}$ is measured by direct RIA and by RIA on extracts of serum after correction with an extraction factor (Hehrmann and Schneider, 1974). Excellent recovery is reported with this assay at extremely high total $T_{4}$ concentrations $(1588 \mathrm{nmol} / \mathrm{l})$. Our findings would therefore suggest that both RIA and CPB techniques on unextracted serum reliably quantitate total serum $T_{4}$.

We gratefully acknowledge financial help from Nicholas Laboratories Ltd, and the King's College Hospital Voluntary Research Fund. We thank 
Professor J. Anderson and Dr C. G. McKerron whose patients were studied.

\section{References}

Bauer, R., Schick, L. A., Phillips, B. F., Rupe, C. O., Gross, J., and Gordon, A. (1970). The use of Sephadex G-25 in the estimation of total serum thyroxine (Abstract). Clin. Chem., 16, 526.

Beckers, C., Cornette, C., and Thalasso, M. (1973). Evaluation of serum thyroxine by radioimmunoassay. J. nucl. Med., 14, 317-320.

Braverman, L. E., Vagenakis, A. G., Foster, A. E., and Ingbar, S. H. (1971). Evaluation of a simplified technique for the specific measurement of serum thyroxine concentration. J. clin. Endocr., 32, 497-502.

Chopra, I. J. (1972). A radioimmunoassay for measurement of thyroxine in unextracted serum. J. clin. Endocr., 34, 938-947.

Gharib, H., Ryan, R. J., Mayberry, W. E., and Hockert, T. (1971). Radioimmunoassay for tri-iodothyronine $\left(T_{3}\right)$. I. Affinity and specificity of the antibody for $\mathrm{T}_{3} . J$. clin. Endocr., 33, 509-516.

Gyde, O. H. B., Hirst, A. D., and Howorth, P. J. N. (1973). An improved method for the mechanized estimation of thyronine-iodine by the bromine-displacement technique. Clin. chim. Acta., 45, 443-447.

Hehrmann, R., and Schneider, C. (1974). Comparison of radioimmunoassay and competitive protein binding assay of total thyroxine in serum (Abstract). Proc. 6th Ann. Meeting Europ. Thyroid Ass., pp. 221-222.

Howorth, P. J. N. and McKerron, C, G. (1974). Evaluation of new kits for the assessment in vitro of thyroid function by determination of serum total thyroxine, free TBG capacity, and free thyroxine index using sephadex G-25 and 125 I-labelled tri-iodothyronine and thyroxine. $J$. clin. Path., 27, 153-161.

Marsden, P. and McKerron, C. G. (1975). Serum triiodothyronine, concentration in the diagnosis of hyperthyroidism. Clin. Endocr., 4, 183-189.

Mitsuma, T., Colucci, J., Shenkman, L., and Hollander, C. S. (1972). Rapid simultaneous radioimmunoassay for triiodothyronine and thyroxine in unextracted serum. Biochem. biophys. Res. Commun., 46, 2107-2113.

Murphy, B. P. (1965). The determination of thyroxine by competitive protein binding analysis employing an anionexchange resin and radiothyroxine. J. Lab. clin. Med., 66, 161-167.

Ratcliffe, W. A., Ratcliffe, J. G., McBride, A. D., Harland, W. A., and Randall, T. W. (1974). The radioimmunoassay of thyroxine in unextracted human serum. Clin. Endocr., 3, 481-488. 